Ius Matrimoniale 32 (2021) $\mathrm{nr} 1$

ISSN 1429-3803; e-ISSN 2353-8120

DOI: http://doi.org/10.21697/im.2021.32.1.02
Artykuł jest udostępniany na zasadach licencji Creative Commons (CC BY-ND 4.0 Międzynarodowe) https://creativecommons.org/licenses/by-nd/4.0/deed.pl

open 2 access (c) (i)

\title{
Przeszkody małżeńskie tajne i publiczne według Codex Iuris Canonici z 1917
}

\author{
Public and occult impediments to marriage pursuant \\ to Codex Iuris Canonici 1917
}

\author{
ks. Tomasz Jakubiak \\ Akademia Katolicka w Warszawie \\ ORCID: 0000-0003-4781-686X \\ e-mail:xjakubiak@poczta.onet.pl
}

Streszczenie: Umiejętność rozróżnienia przeszkód małżeńskich tajnych (impedimenta occulta) i przeszkód publicznych (impedimenta publica) okazuje się konieczna przy stosowaniu norm prawa kanonicznego Kościoła katolickiego. Do tego podziału odwołują się przepisy KPK/83 i KKKW dotyczące: dyspensowania od przeszkód małżeńskich (kan. $1079 \$ 3 \mathrm{KPK} / 83$, kan. $796 \$ 2 \mathrm{KKKW}$ ), zapisu faktu udzielenia dyspensy (kan. 1082 KPK/83, kan. 799 KKKW), a także uważnienia małżeństwa (kan. 1158-1159 KPK/83, kan. 845-846 KPK/83).

Dostrzegając brak jednomyślności wśród współczesnych kanonistów co do tego, jak należy interpretować ustawową definicję przeszkody publicznej i tajnej, zapisaną w kan. 1074 KPK/83 i kan. $791 \mathrm{KKKW}$, autor niniejszego artykułu postanowił przeanalizować kształtowanie się doktryny i dyscypliny Kościoła katolickiego w tej materii w latach 1917-1983, czyli w okresie obowiązywania norm ogłoszonych w kodeksie Pio-Benedyktyńskim. Metoda ta wydaje się odpowiednia ze względu na fakt, że we wszystkich kodeksach Kościoła katolickiego promulgowanych po 1917 roku ustawodawca w ten sam sposób definiował przeszkodę publiczną i przeszkodę tajną (Publicum censetur impedimentum, quod probari in foro externo potest; secus est occultum). Wnioski z badań przeprowadzonych na potrzeby niniejszego opracowania ukazują również przyczyny, które miały wpływ na brak jednoznaczności w określeniu zakresu przywołanych przeszkód w doktrynie i dyscyplinie Kościoła w latach 1917-1983.

Słowa kluczowe: małżeństwo, przeszkoda małżeńska, przeszkoda tajna, przeszkoda publiczna

Abstract: The ability to distinguish between occult marital impediments (impedimenta occulta) and public marital impediments (impedimenta publica) proves to be necessary for the application of the norms of canon law in the Catholic Church. This distinction is referred to in the provisions of $\mathrm{CIC} / 83$ and CCEO concerning: dispensation from marital impediments (can. $1079 \$ 3 \mathrm{CIC} / 83$; can. $796 \$ 2 \mathrm{CCEO}$ ), noting the fact of granting 
dispensation (can. $1082 \mathrm{CIC} / 83$; can. 799 CCEO), and the convalidation of marriage (can. 1158-1159 CIC/83; can. 845-846 CCEO).

Noting the lack of unanimity among today's canonists as regards interpretation of the statutory definition of public and occult impediments provided for in can. $1074 \mathrm{CIC} / 83$ and can. 791 CCEO, the author of this article has endeavored to analyze the development of the doctrine and discipline of the Catholic Church in this matter in the years 1917-1983, i.e. the period when the norms announced in the Pio-Benedictine Code were in force. This method seems appropriate in view of the fact that in all codes of the Catholic Church promulgated after 1917, the legislator defined public impediment and occult impediment in the same way (Publicum censetur impedimentum, quod probari in foro externo potest; secus est occultum). The conclusions of studies performed for the purpose of this paper also show the reasons for the ambiguous definition of the scope of said impediments in the doctrine and discipline of the Church in the years 1917-1983. (ttum. Małgorzata Wójcik) Keywords: marriage, marital impediment, occult impediment, public impediment

Treść: Wstęp. 1. Urzędowe interpretacje prawa i praktyka Kurii Rzymskiej. 2. Opinie uczonych. Zakończenie

\section{Wstęp}

W Kodeksie prawa kanonicznego z 1983 roku ustawodawca zdefiniował pojęcie przeszkody małżeńskiej publicznej i tajnej. Zgodnie z normą zapisaną w kan. $1074 \mathrm{KPK} / 83$ : „przeszkodę uważa się za publiczną, jeśli może być udowodniona w zakresie zewnętrznym; poza tym jest tajna" (Publicum censetur impedimentum, quod probari in foro externo potest; secus est occultum) ${ }^{1}$. Identycznie zapisana norma promulgo-

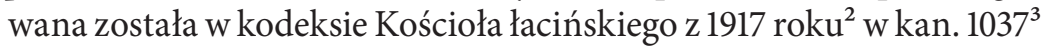
oraz Kodeksie kanonów Kościołów wschodnich w kan. 791 ${ }^{4}$. Przedkodeksowe prawo małżeńskie katolickich Kościołów wschodnich

1 Codex Iuris Canonici auctoritate Ioannis Pauli PP. II promulgatus, 25.01.1983, AAS 75 (1983), pars II, s. 1-317 (dalej: KPK/83).

2 Codex Iuris Canonici Pii X Pontificis Maximi iussu digestus. Benedicti Papae XV auctoritate promulgatus, 15.09.1917, Romae 1917, AAS 9 (1917) II (dalej: CIC/17).

3 Różnica dotyczyła jedynie interpunkcji, a dokładnie przecinka, który nie występował przed słowem „quod”.

4 Codex Canonum Ecclesiarum Orientalium auctoritate Ioannis Pauli PP. II promulgatus, 18.10.1990, Typis Polyglottis Vaticanis 1990; tłumaczenie polskie: Kodeks kanonów Kościołów wschodnich promulgowany przez papieża Jana Pawła II 
promulgowane przez papieża Piusa XII przeszkodę publiczną opisywało nieco inaczej. W kan. $27 \mathrm{CA}^{5}$ zapisane zostało: Publicum censetur impedimentum quod publico ex facto oritur vel quod alio modo probari in foro externo potest; secus est occultum.

Umiejętność rozróżnienia przeszkód małżeńskich tajnych (impedimenta occulta) i przeszkód publicznych (impedimenta publica) okazuje się konieczna przy stosowaniu norm prawa kanonicznego Kościoła katolickiego. Do tego podziału odwołują się obecnie obowiązujące przepisy KPK/83 i KKKW dotyczące: dyspensowania od przeszkód małżeńskich (kan. 1079 \$3 KPK/83; kan. $796 \$ 2$ KKKW), zapisu faktu udzielenia dyspensy (kan. 1082 KPK/83; kan. 799 KKKW), a także uważnienia małżeństwa (kan. 1158-1159 KPK/83; kan. 845-846 KKKW).

Dostrzegając brak jednomyślności wśród współczesnych autorów co do tego, jak należy interpretować ustawową definicję przeszkody publicznej i tajnej, zapisaną w kan. 1074 KPK/83 i kan. 791 KKKW, autor niniejszego artykułu postanowił przeanalizować kształtowanie się doktryny i dyscypliny Kościoła katolickiego w tej materii w latach 1917-1983, czyli w okresie obowiązywania norm kodeksu Pio-Benedyktyńskiego. Metoda ta wydaje się odpowiednia ze względu na fakt, że - jak już wcześniej zaznaczono - we wszystkich kodeksach Kościoła katolickiego promulgowanych po 1917 roku ustawodawca $\mathrm{w}$ ten sam sposób opisywał przeszkodę publiczną i przeszkodę tajną (Publicum censetur impedimentum, quod probari in foro externo potest; secus est occultum).

Zgodnie z definicją ustawową zapisaną w can. 1037 CIC/17 przeszkodami publicznymi (impedimenta publica) były te przeszkody, które mogły być udowodnione w zakresie zewnętrznym. W przeciwnym razie, jeśli nie można było istnienia udowodnić w zakresie zewnętrznym, określane były terminem "przeszkody tajne”

(18.10.1990), Wydawnictwo Archidiecezji Lubelskiej „Gaudium”, Lublin 2002 (dalej: KKKW).

${ }^{5}$ CA - skrót od: PIUs XII, Motu proprio de disciplina sacramenti matrimonii pro Ecclesia Orientali Crebrae allatae sunt, 22.02.1949, AAS 41 (1949), s. 89-119. 
(impedimenta occulta). Prawodawca, mówiąc w pierwszym kodeksie Kościoła łacińskiego o przeszkodach małżeńskich, rozróżniał ponadto przypadki publiczne i przypadki tajne (istnienia) przeszkody (can. 1045 CIC/17), a także przeszkody z natury swojej publiczne (impedimenta natura sua publica) i przeszkody z natury swojej tajne (impedimenta natura sua occulta) (can. $1971 \$ 1$ n. 2 CIC/17). W uchwyceniu desygnatów przywołanych pojęć i istniejących między nimi różnic pomocne okazują się ustawowe interpretacje prawa (can. $16 \$ 1-2$ CIC/17), praktyka Kurii Rzymskiej oraz powszechna i stała opinia uczonych (can. $16 \$ 3,18,20 \mathrm{CIC} / 17$ ).

\section{Urzędowe interpretacje prawa i praktyka Kurii Rzymskiej}

Zanim zostaną przywołane dokumenty Stolicy Apostolskiej wydane po wejściu w życie kodeksu Pio-Benedyktyńskiego, dotyczące przywołanej materii, warto przytoczyć kilka wybranych wyroków trybunałów Stolicy Apostolskiej, w których orzekały one o nieważności małżeństwa z powodu bojaźni. Chociaż wydane zostały przed 1917 rokiem, pozwalają uchwycić jurysprudencję dykasterii Stolicy Apostolskiej w sprawach małżeńskich w okresie, kiedy trwały prace nad kodeksem Kościoła łacińskiego.

Z wyroku Roty Rzymskiej wydanego w 1911 roku dowiadujemy się, że publiczny charakter przeszkody (a dokładnie w tym przypadku bojaźni), uniemożliwiający uzdrowienie małżeństwa w inny sposób niż przez ponowienie zgody $\mathrm{w}$ formie kanonicznej, tożsamy jest z jej publicznym charakterem w sensie prawnym (est publicus in sensu iuris) ${ }^{6}$, czyli - zdaniem komentatorów tego wyroku - z możliwością przeprowadzenia dowodu w trakcie procesu sądowego ${ }^{7}$. Kolejny wyrok trybunału Roty Rzymskiej z 1915 roku, potwierdzony w 1916 roku przez tę samą dykasterię, wskazuje, że przeszkodą publiczną jest

\footnotetext{
6 Sacra Romana Rota, Nullitatis matrimonii (Andrassy-Széchényi), c. Michael Lega, 2.06.1911, AAS 4 (1915), s. 115.

7 Canon Law Digest. Officially Published Documents Affecting the Code of Canon Law 1917-1933, vol. 1, T.L. Bouscaren (red.), Milwaukee 1934, s. 525.
} 
ta, która może zostać udowodniona na forum zewnętrznym (impedimento publico, quod, nempe, in foro externo probari potest $)^{8}$. Z kontekstu orzeczenia można domniemywać, że wyrokujący sędziowie przez możliwość przeprowadzenia dowodu na forum zewnętrznym rozumieli możliwość udowodnienia, zgodnie z prawem kościelnym, zawarcia małżeństwa mimo istnienia przeszkody. Na uwagę zasługuje fakt, że użyte w uzasadnieniu wyroku określenie przeszkody publicznej zgodne jest z definicją tejże przeszkody, zapisaną w kodeksach prawa Kościoła katolickiego z lat 1917, 1983, 1991.

Wcześniej w ten sam sposób uzasadniała swoje wyroki w sprawach małżeńskich Kongregacja Soboru. Rozpatrując nieważność małżeństwa zawartego pod wpływem bojaźni, stwierdziła, że nie ma możliwości konwalidacji małżeństwa nieważnie zawartego z powodu przeszkody publicznej bez ponownego wyrażenia zgody w formie prawnej ${ }^{9}$. Mówiąc o przeszkodzie publicznej, jak wynika z kontekstu wyroku, sędziowie mieli na myśli możliwość udowodnienia jej istnienia $\mathrm{w}$ trakcie procesu sądowego ${ }^{10}$.

Jednym z pierwszych papieskich dokumentów wydanych po 1917 roku, pośrednio odnoszącym się do przedmiotowego zakresu normy zapisanej w can. 1037 CIC/17, jest konstytucja apostolska Servatoris Iesu Christi z 1925 roku. W dokumencie tym papież Pius XI rozróżniał impedimenta prorsus occulta i impedimenta occulta. Zapowiadając rozszerzenie jubileuszu obchodzonego w Rzymie na cały świat katolicki, biskup rzymski upoważnił spowiedników do udzielania dyspensy na forum wewnętrznym sakramentalnym od: a) (ab) impedimento prorsus occulto pokrewieństwa w trzecim lub drugim stopniu linii bocznej, dotykającym pierwszego, a pochodzącej ex generatione

\footnotetext{
8 Sacra Romana Rota, Nullitatis matrimonii (Pic-Garreaud), c. Ioannes Prior, 21.05.1915, AAS 8 (1916), s. 51; SACRA Romana Rota, Nullitatis matrimonii (Pic-Garreaud), c. Guilelmus Sebastianelii, 26.04.1916, AAS 9 (1917-I), s. 144-150.

9 Sacra Congregatio Sancti Concilit, Mohiloven. seu Tiraspolen., 9.07.1881, 10.09.1881, w: P. Gasparri, Codicis Iuris Canonici Fontes, vol. 6, Roma 1962, n. 4253, s. 640 .

10 S. Biskupski, Prawo małżeńskie Kościoła rzymskokatolickiego, t. 1, Warszawa 1956, s. 106.
} 
illictta, ale jedynie w celu konwalidacji małżeństwa przy nakazie odnowienia konsensu, nie zaś do zawarcia małżeństwa, względnie do uzdrowienia go in radice; b) tajnej przeszkody criminis, gdy żadna strona nie współdziała, bez względu na to, czy chodzi o zawarcie małżeństwa, czy też o małżeństwo już zawarte, w ostatnim jednakże wypadku należy polecić prywatne odnowienie zgody, według kanonu 1135, a w obu wypadkach należy nałożyć długą i zbawienną pokutę ${ }^{11}$. Niestety, w prawie obowiązującym po promulgacji kodeksu Pio-Benedyktyńskiego termin impedimenta prorsus occulta nie był znany.

Na niejasność normy dotyczącej podziału przeszkód małżeńskich zapisanej w can. 1037 CIC/17 wskazywać może fakt, że o ustawową interpretację wyrażeń w niej zapisanych została poproszona Papieska Komisja ds. Autentycznej Interpretacji Kanonów Kodeksu. Dnia 25 czerwca 1932 roku dykasteria, odpowiadając na przedłożone jej pytanie, potwierdziła, że do uznania przeszkody za publiczną (impedimentum publicum) w rozumieniu can. $1037 \mathrm{CIC} / 17$ wystarczające jest to, że fakt, z którego przeszkoda wynika, stał się publiczny (sufficiat ut publicum sit factum ex quo oritur impedimentum $)^{12}$. Niestety, Papieska Komisja wyjaśniając jeden niejasny termin, posłużyła się kolejnym terminem: „fakt publiczny”.

Mówiąc o autentycznej interpretacji can. 1037 CIC/17, nie sposób nie wspomnieć w tym miejscu o kolejnym wyroku Roty Rzymskiej z 1928 roku. Dotyczył on nieważności małżeństwa zawartego pomimo istnienia przeszkody występku (impedimentum criminis). Sędziowie trybunału, odwołując się do pojęcia przeszkody z natury

11 PIUs XI, Constitutio apostolica Universale Iubilaeum Anno Domini Millesimo Nongentesimo Vicesimo Quinto in Urbe Celebratum ad Totum Catholicum Orbem Extenditur Servatoris Iesu Christi, n. X, 25.12.1925, AAS 17 (1925), s. 617. Tekst polski: PIUs XI, Konstytucja apostolska Sacerdotis Iesu Christi, na stronie https://opoka. org.pl/biblioteka/W/WP/pius_xi/konstytucje/jubileusz_25121925.html (dostęp 2.01.2021 r.).

12 Pontificia Commissio ad Codicis Canones Authentice Interpretandos, Responsa ad proposita dubia, n. II, 25.06.1932, AAS 24 (1932), s. 284. 
swojej publicznej (impedimenta natura sua publica) ${ }^{13}$, o której była mowa w can. $1917 \$ 1 \mathrm{n}$. 2 CIC/17, stwierdzili, że nie odnosi się ono do przeszkód publicznych (impedimenta publica), o których mowa w can. 1037 CIC/17.

Zanim przejdziemy do dalszej analizy przedmiotowego rozstrzygnięcia, konieczne wydaje się przybliżenie czytelnikowi pojęcia przeszkody z natury swojej tajnej i przeszkody z natury swojej publicznej. Choć nie były one zdefiniowane w CIC/17, to jednak były dobrze znane prawnikom przedkodeksowym. Sam ustawodawca do tego podziału nawiązał wprost raz jeden - w can. 1971 n. 2 CIC/17 ${ }^{14}$. Przeszkody z natury swojej publiczne opierały się na fakcie z natury swojej publicznym. Do takich faktów zaliczano: pokrewieństwo ślubne ${ }^{15}$ (can. 1076 CIC/17), powinowactwo (can. 1077 CIC/17), przyzwoitość publiczną (can. $1078 \mathrm{CIC} / 17)$, pokrewieństwo duchowe i prawne (can. 1079-1080 CIC/17), wiek (can. 1067 CIC/17), różność religii (can. 10701071 CIC/17), związek małżeński (can. 1069 CIC/17), wyższe święcenia (can. 1072 CIC/17), ślub publiczny zwykły i uroczysty (can. 1073 CIC/17). Przeszkoda $z$ natury swojej tajna powstawała natomiast z faktu, który sam z siebie z natury swojej był tajny - np. cudzołóstwo z obietnicą małżeństwa (can. $1075 \mathrm{CIC} / 17$ ), niezdolność płciowa (can. $1068 \mathrm{CIC} / 17$ ), pokrewieństwo nieślubne (can. $1076 \mathrm{CIC} / 17)^{16}$.

Skoro pokrótce zostały przybliżone pojęcia przeszkód z natury publicznych i tajnych, powróćmy do przerwanego wątku. Treść uzasadnienia wyroku z 11 sierpnia 1928 roku nawiązywała do rozpatrywanego w sprawie sądowej przypadku, w którym przeszkoda ze swej natury tajna okazała się być przeszkodą publiczną w rozumieniu can.

13 R.D. 20-402, 11.08.1928; opis procesu w: Canon Law Digest. Officially Published Documents Affecting the Code of Canon Law 1933-1942, vol. 2, T.L. BousCaren (red.), Milwaukee 1934, s. 293-295; 543-544.

14 Can. $1971 \$ 1 \mathrm{CIC} / 17$ : Habiles ad accusandum sunt: $2^{\circ}$ Promotor iustitiae in impedimentis natura sua publicis.

15 Po promulgacji kodeksu nie istniało już rozróżnienie między pokrewieństwem wynikającym z małżeństwa i związku niemałżeńskiego.

16 F. Bączkowicz, J. Baron, W. Stawinoga, Prawo kanoniczne. Podręcznik dla duchowieństwa, t. 2, Opole 1958, s. 181. 
$1037 \mathrm{CIC} / 17^{17}$. Uzasadnienie to było o tyle ciekawe, że sędziowie nie stawiali znaku równości pomiędzy przeszkodami publicznymi ze swej natury i przeszkodami publicznymi. Przeszkoda mająca za podstawę fakt sam z siebie publiczny, nie była według nich tożsama z przeszkodą opartą na fakcie publicznym. Wyrok ten znajduje swoje potwierdzenie w autentycznej interpretacji can. 1037 CIC/17 dokonanej przez Papieską Komisję ds. Autentycznej Interpretacji Kanonów w 1932 roku. Życie bowiem dostarczało dowodów na istnienie przeszkód małżeńskich tajnych mimo tego, iż fakty (przyczyny), z których się wywodziły, były publiczne ze swej natury.

Analiza systemu prawa kanonicznego dowodzi jednoznacznie, że przeszkoda tajna może stać się przeszkodą publiczną (can. 1047 CIC/17). Promulgowane po 1917 roku kodeksy także dopuszczają istnienie takiej możliwości (kan. 1082 KPK/83; kan. 799 KKKW). W normie regulującej zapisanie faktu udzielenia dyspensy na forum wewnętrznym niesakramentalnym, ustawodawca stwierdził, że jeśli czego innego nie postanawia reskrypt Penitencjarii, dyspensa od przeszkody tajnej udzielona w zakresie wewnętrznym niesakramentalnym powinna być wpisana do księgi przechowywanej w tajnym archiwum kurii, o czym wspomniano w kan. 379 CIC/17, i nie jest potrzebna inna dyspensa w zakresie zewnętrznym, gdy przeszkoda tajna stanie się później publiczną.

$\mathrm{Na}$ to, jak sama Stolica Apostolska pojmowała przeszkody tajne i publiczne, może rzucić światło również promulgowane przez Piusa XII w 1949 roku motu proprio Crebrae allatae sunt, w którym zawarte zostały normy regulujące dyscyplinę katolickich Kościołów wschodnich w sprawach małżeńskich. W kan. 27 CA zapisana została w odmienny nieco sposób niż w can. 1037 CIC/17 definicja przeszkód publicznych i tajnych. Zgodnie z przywołanym przepisem przeszkoda jest uważana za publiczną, ponieważ powstaje $z$ faktu publicznego albo może być dowiedziona $\mathrm{w}$ inny sposób na forum zewnętrznym (Publicum censetur impedimentum quod publico ex facto oritur vel

17 Canon Law Digest. Officially Published Documents Affecting the Code of Canon Law 1933-1942, vol. 2..., s. 544. 
quod alio modo probari in foro externo potest; secus est occultum). W stosunku do definicji przeszkód publicznych zapisanej w kodeksie Kościoła łacińskiego ustawodawca doprecyzował, co nie było jednak konieczne, że przeszkodami publicznymi są również te, które opierają się na publicznym fakcie, a nie tylko te, które mogą być dowiedzione innymi środkami na forum zewnętrznym. Doprecyzowanie definicji przeszkody publicznej zapisanej w kan. 27 CA w stosunku do normy zapisanej w kan. 1037 CIC/17 z pewnością było następstwem autentycznej interpretacji przedmiotowej normy, dokonanej przez Papieską Komisję ds. Autentycznej Interpretacji Kanonów Kodeksu 25 czerwca 1932 roku $^{18}$.

\section{Opinie uczonych}

Kodeks Pio-Benedyktyński pojęcie przeszkody publicznej i przeszkody tajnej definiował w odmienny sposób, niż to czynili kanoniści przed 1917 rokiem. Przy lekturze późniejszych opracowań kan. 1037 CIC/17 trzeba zatem zachować ostrożność, gdyż w niektórych analizach przedmiotowego kanonu można spotkać się z próbami zharmonizowania pokodeksowej koncepcji podziału przeszkód na tajne i publiczne $\mathrm{z}$ opiniami kanonistów sformułowanymi przed promulgacją kodeksu. Takim działaniom przeciwstawiał się Woywod ${ }^{19}$. Wcześniej istniejący podział przeszkód był bowiem źródłem wielu komplikacji ${ }^{20}$. Odniesienie nowego prawa do starego mogło zatem nastręczyć również trudności.

W przedkodeksowych komentarzach prawa kościelnego rozróżniano przeszkody omnino occultum i przeszkody simpliciter occultum. Niestety, kanoniści i w tym przypadku nie byli zgodni

\footnotetext{
18 Pontificia Commissio Ad Codicis Canones Authentice Interpretandos, Responsa ad proposita dubia, n. II, 25.06.1932, AAS 24 (1932), s. 284.

19 S. Woywod, A Practical Commentary on The New Canon Law, vol. 1, New YorkLondon 1948, s. 671.

20 A.B. Meenan, The New Canon Law in its Practical Aspects, American Ecclesiastical Review, The Dolphin Press Philadelphia 1918, s. 149; J.J. Ch. Petrovits, New Church Law on Matrimony, Philadelphia 1919, s. 73.
} 
w zdefiniowaniu tych pojęć. Przywołany już Woywod stwierdził, że przeszkodami omnino occultum były te przeszkody, których nie można było udowodnić na forum zewnętrznym, ponieważ żadna osoba mogąca składać zeznania w sprawie nie miała wiedzy o przeszkodach. Autor zauważył, że dla uznania przeszkody za omnino occultum nie miało znaczenia, że o jej istnieniu wiedziały strony, spowiednik, jedna lub dwie osoby. Jeśli chodzi o przeszkody simpliciter occultum, o ich istnieniu mogło wiedzieć więcej osób. Jak wynikało z praktyki Penitencjarii Apostolskiej przy udzielaniu dyspens od przeszkód małżeńskich, tajnego ich charakteru nie zmieniał fakt, że oprócz spowiednika i stron o ich istnieniu wiedziało kilka osób (5-6 osób w miasteczku, 7-8 w mieście ${ }^{21}$ ). Warunkiem uznania przeszkody za simpliciter occultum było to, że ci, którzy o ich istnieniu wiedzieli, powinni być na tyle dyskretni, by nie upublicznić przeszkody ${ }^{22}$.

Wernz, wskazując na różnice występujące pomiędzy przeszkodami omnino occultum i simpliciter occultum, zwrócił uwagę na cel, dla którego odwoływano się do tego podziału. Rozróżnienie tych terminów w praktyce zależne było od tego, czy dokonywało się po to, by określić podmioty kompetentne do udzielenia dyspensy od przeszkody małżeńskiej, czy ze względu na konwalidację nieważnie zawartego małżeństwa w obliczu Kościoła. Gdy chodziło o dyspensowanie, kładziono nacisk na wiedzę (notitio) innych osób o przeszkodzie. Przeszkodą omnino occultum była ta, która nie była znana nikomu z wyjątkiem stron i spowiednika, przynajmniej jeśli chodzi o zawieranie małżeństwa, jakkolwiek w małżeństwach już zawartych uznawano przeszkodę omnino occultum także wtedy, jeśli była znana przez jedną osobę. Różnica ta wypływała z faktu, że zeznanie jednego świadka wystarczało do tego, by przeszkodzić celebracji małżeństwa do czasu dowiedzenia braku przeszkody lub uzyskania od niej dyspensy. Po

\footnotetext{
21 Gasparri przytoczył sytuację, w której Penitencjaria udzieliła dyspensy od przeszkody małżeńskiej, mimo że o jej istnieniu wiedziało 7 lub 8 osób w mieście liczącym 9 tysięcy mieszkańców - P. GASPARri, Tractatus canonicus de matrimonio, v. 1, Parisiis 1904, n. 260, s. 164.

22 S. Woywod, A Practical Commentary on The New Canon Law, vol. 1..., s. 671-672.
} 
zawarciu małżeństwa natomiast zeznanie jednego świadka nie wystarczało do tego, by udowodnić w sądzie nieważność małżeństwa ${ }^{23}$. Według kanonisty po promulgacji kodeksu Pio-Benedyktyńskiego przedkodeksowa przeszkoda omnino occultum - to jest taka, która nie jest znana nikomu z wyjątkiem stron i spowiednika, i może jednej (ponadto) osoby - była przeszkodą rzeczywiście (faktycznie) tajną (Ex dictis apparet iure novo facto occultum ${ }^{24}$ dumtaxat haberi illud impedimentum, que iure precedente dicebatur omnino occultum... $)^{25}$.

Jak zauważa Wernz, przy ocenie ważności małżeństwa nieważnie zawartego w formie prawnej i potem konwalidowanego, nie zwracano już uwagi na rzeczywistą wiedzę innych osób o przeszkodzie. Impedimentum occultum była ta przeszkoda, której istnienia nie można było udowodnić w sądzie kościelnym ${ }^{26}$.

Wśród przedkodeksowych autorów znany był podział przeszkód małżeńskich na przeszkody publiczne i tajne formalnie bądź materialnie (formaliter vel materialiter). Terminy te stosowano głównie do przeszkód mających za przyczynę przestępstwo ${ }^{27}$. Podział ten nawiązywał do zapisu can. 2197 CIC/17. Ustawodawca, biorąc pod uwagę czynnik rozgłosu przestępstwa ${ }^{28}$, dokonał w przywołanym kanonie podziału przestępstw na: publiczne (delictum publicum), notoryczne (notorium notorietate iuris vel facti) i tajne (ocultum formaliter vel materialiter $)^{29}$. Do przestępstw publicznych zaliczano te, które były powszechnie znane, czyli rozgłoszone albo popełnione

23 F. Xav. Wernz, P. Vidal, Ius Canonicum, t. V. Ius Matrimoniale, Roma 1946, s. 178-179 (przywołane fragmenty tłumaczył Robert Sochań).

24 Zwykle w nawiasach teksty łacińskie są napisane kursywą. Jednakże czasami napisane są tylko w części kursywą po to, aby odzwierciedlić zapis tekstu oryginalnego.

25 F. Xav. Wernz, P. Vidal, Ius Canonicum, t. V. Ius Matrimoniale..., s. 180.

26 TAMŻE, s. 178-180.

27 S. Woywod, A Practical Commentary on The New Canon Law, vol. 1..., s. 671-672.

28 Woywod mówił o „czynniku rozgłosu”. Zdarzali się autorzy, którzy przy tym podziale zwracali uwagę na „kryterium możliwości udowodnienia”.

29 Can. 2197 CIC/17: Delictum est:

$1^{\circ}$ Publicum, si iam divulgatum est aut talibus contigit seu versatur in adiunctis ut prudenter iudicari possit et debeat facile divulgatum iri; 
w takich okolicznościach, że rozumnie można przypuszczać, że wnet zostaną rozgłoszone ${ }^{30}$. Notorycznymi były przestępstwa tak oczywiste, że w żaden sposób nie można było ich ukryć lub usprawiedliwić. Zgodnie z can. 1747 n. 1 CIC/17 przestępstwa notoryczne nie wymagały dowodu w sądzie ${ }^{31}$. Jeśli zostały stwierdzone wyrokiem sądowym, który przeszedł w stan rzeczy osądzonej, albo gdy winny z zachowaniem normy zapisanej w can. 1750 CIC/17 przyznał się przed sądem do ich popełnienia, były określane jako prawnie notoryczne. O przestępstwach faktycznie notorycznych mowa jest wtedy, gdy czyn przestępczy jest tak publiczny, iż żadnym wykrętem nie można go ukryć, a poczytalność sprawcy jest tak pewna, że w żaden legalny sposób nie można jej wykluczyć. Zdaniem Bączkowicza przestępstwo publiczne tym różniło się od notorycznego, że przy przestępstwach publicznych znany jest jedynie fakt popełnienia czynu przestępczego, a nie poczytalność sprawcy, która dla odmiany dodatkowo jest pewna przy przestępstwach notorycznych. Notoryczność przestępstwa nie

$2^{\circ}$ Notorium notorietate iuris, post sententiam iudicis competentis quae in rem iudicatam transierit aut post confessionem delinquentis in iudicio factam ad normam can. 1750;

$3^{\circ}$ Notorium notorietate facti, si publice notum sit et in talibus adiunctis commissum, ut nulla tergiversatione celari nulloque iuris suffragio excusari possit;

$4^{\circ}$ Occultum, quod non est publicum; occultum materialiter, si lateat delictum ipsum; occultum formaliter, si eiusdem imputabilitas.

30 Sztafrowski uważał, że przestępstwa publiczne tym różnią się od przeszkód publicznych, że w przypadku pierwszych bierze się pod uwagę sam fakt rozgłoszenia, dotarcia do pewnej grupy osób. Według niego w przypadku publicznych przeszkód bierze się natomiast pod uwagę możliwość udowodnienia, czyli rozgłoszenia, które na razie nie musi istnieć. Autor, powołując się na autentyczną interpretację can. 1037 CIC/17 z dnia 25.06.1932 r., dotyczącą przeszkód publicznych i tajnych, twierdził, że Penitencjaria Apostolska zwykła udzielać dyspens wyłącznie od przeszkód zarówno z natury swojej, jak i okoliczności, tajnych. Analizując kontekst wypowiedzi Sztafrowskiego, można się pokusić o stwierdzenie, że gdy ów kanonista mówił o dyspensowaniu od przeszkód co do okoliczności tajnych, w rzeczywistości miał na myśli przeszkody tajne - E. SzTAFrowski, Prawo kanoniczne w okresie odnowy soborowej. Podręcznik dla duchowieństwa, t. 2, Warszawa 1979, s. 255.

31 Can. 1747 CIC/17: Non indigent probatione: $1^{\circ}$ Facta notoria, ad normam can. 2197, nn. 2, 3. 
była tożsama z jego publicznością, nie musiało ono bowiem być rozgłoszone ani nie musiała zachodzić możliwość jego rozgłoszenia.

Według normy zapisanej w can. 2197 n. 4 CIC/17 przestępstwo, które nie jest publiczne, jest przestępstwem tajnym. Przestępstwo occultum materialiter zachodziło wtedy, kiedy fakt popełnienia czynu przestępczego był nieznany, occultum formaliter - gdy fakt popełnienia czynu przestępczego był znany publicznie, ale nie można tego przestępstwa przypisać sprawcy - nie jest znana przypisywalność. Biorąc pod uwagę, że przestępstwem tajnym mogły być przestępstwa, które nie zostały rozgłoszone i nie ma obawy, że zostaną rozgłoszone, termin occultum z can. 2197 n. 4 CIC/17 nie pokrywał się z terminem occultum zapisanym w can. $1037 \mathrm{CIC} / 17^{32}$. Fakt rozgłoszenia istnienia przeszkody nie musi być bowiem tożsamy z możliwością udowodnienia jej w sądzie. Mocno podkreślił to Wernz. Zauważył, że do pojęcia przeszkody publicznej nie należy jako taka wiedza (notitia) o niej, to jest rozpowszechnienie (divulgatio) wiedzy o niej, lecz możliwość przeprowadzenia dowodu o jej istnieniu ${ }^{33}$.

Bazując na podziale dokonanym w can. 2197 CIC/17, niektórzy kanoniści przedkodeksowi słowo publicum tłumaczyli jednakowo dla przeszkód i przestępstw. Kiedy przestępstwo było publiczne i sprawca był znany, ale nie miano świadomości, że z przestępczego działania powstawała przeszkoda, według nich była ona tajna formaliter i jednocześnie publiczna materialiter. Pogląd ten nie był jednak powszechnie akceptowany. Nie zgadzali się z nim między innymi Benedykt XIV i Gasparri ${ }^{34}$.

Kończąc tę część rozważań poświęconych wpływowi interpretacji słowa publicum z can. 2197 n. 4 CIC/17 na wykładnię can. 1037 CIC/17, warto zauważyć, że norma zapisana w can. 2197 CIC/17 wraz z promulgacją kodeksu w 1983 roku została abrogowana.

\footnotetext{
32 F. Bączkowicz, J. Baron, W. Stawinoga, Prawo kanoniczne. Podręcznik dla duchowieństwa, t. 3, Opole 1958, s. 23.

33 F. Xav. Wernz, P. Vidal, Ius Canonicum, t. V. Ius Matrimoniale..., s. 178.

34 S. Woywod, A Practical Commentary on The New Canon Law, vol. 1..., s. 671-672.
} 
Jak zauważył Woywod, na brak jednoznaczności w określeniu przez Stolicę Apostolską i komentatorów kodeksu Pio-Benedyktyńskiego desygnatów pojęć impedimentum occultum i impedimentum publicum, zapisanych w can. 1037 CIC/17, duży wpływ miały normy upoważniające Penitencjarię Apostolską do udzielania dyspens na forum wewnętrznym od przeszkód małżeńskich tajnych (can. $258 \$ 1$ CIC/17, 1031 \$ 2 n. 1, 1047 CIC/17). Przyczyniały się do tego, że mimo zdefiniowania w sposób wyraźny przez ustawodawcę przywołanych pojęć w can. 1037 CIC/17, wciąż odwoływano się do prawa obowiązującego przed 1917 rokiem $^{35}$. Penitencjaria Apostolska po promulgacji kodeksu Pio-Benedyktyńskiego dużą uwagę przy udzielaniu dyspens od przeszkód tajnych koncentrowała na możliwości ich rozgłoszenia $^{36}$. Czyli słowo publicum było interpretowane w myśl can. 2197 CIC/17, a nie can. $1037 \mathrm{CIC} / 17$.

Nie bez znaczenia dla powrotu do starego prawa przy interpretowaniu przepisów kodeksu Pio-Benedyktyńskiego było również przyznanie przez ustawodawcę promotorowi sprawiedliwości, w can. 1971 n. 2 CIC/17, prawa do wniesienia skargi o stwierdzenie nieważności małżeństwa wtedy, gdy wpłynęło do niego lub ordynariusza zawiadomienie o nieważności małżeństwa zawartego mimo istnienia przeszkody z natury swej publicznej ${ }^{37}$. Chociaż takie określenie przeszkody małżeńskiej nie znalazło się w części kodeksu wprost poświęconej prawu małżeńskiemu, to jednak przed 1917 rokiem było używane do opisu przeszkód małżeńskich tajnych i publicznych ${ }^{38}$. Stąd liczni autorzy w swoich opiniach na temat can. 1037 CIC/17 odwoływali się również do takiego podziału przeszkód małżeńskich.

Wszyscy kanoniści uważali zgodnie, że aby uznać przeszkodę za możliwą do udowodnienia na forum zewnętrznym (czyli za publiczną), musi istnieć możliwość przeprowadzenia dowodu w rozumieniu

\footnotetext{
35 TAMŻE, s. 672.

36 S. Biskupski, Prawo małżeńskie Kościoła rzymskokatolickiego..., s. 107.

37 Can. $1971 \$ 1$ CIC/17. Habiles ad accusandum sunt: $2^{\circ}$ Promotor iustitiae in impedimentis natura sua publicis.

38 S. Woywod, A Practical Commentary on The New Canon Law, vol. 1..., s. 672.
} 
prawa procesowego. Taki dowód może opierać się na zeznaniach świadków (can. 1756-1791, 1975 CIC/17), na dokumentach prywatnych lub publicznych (can. 1812-1824 CIC/17) ${ }^{39}$, zgodnych opiniach dwóch biegłych potwierdzonych innymi dowodami, domniemaniu prawnym, fakcie notorycznym (can. $1747 \mathrm{CIC} / 17)^{40}$. Jednakże na tym kończyła się ich zgodność.

Jak już wcześniej zauważono za Woywodem, wśród uczonych analizujących can. 1037 CIC/17 pojawiały się tendencje do tłumaczenia przepisów ogłoszonego w 1917 roku kodeksu, prawem obowiązującym wcześniej. Próby pogodzenia starego prawa z nowym nie zawsze dawały zrozumiałe rezultaty, a czasami wręcz rozmywały znaczenie pojęcia przeszkody publicznej, które miało być zrozumiałe dzięki zdefiniowaniu go przez ustawodawcę w can. 1037 CIC/17. Przykłady takich działań można znaleźć u Grabowskiego. W swojej analizie przedmiotowej normy odwoływał się on do can. 2197 CIC/17. Do przeszkód publicznych zaliczał nie tylko te, które mogą zostać udowodnione na forum kościelnym, ale również przeszkody mające za podstawę fakt znany w społeczeństwie. Tym samym stawiał znak równości między przeszkodami publicznymi i rozgłoszonymi. Ponadto do przeszkód publicznych zaliczył przeszkody z natury swojej publiczne. Takie rozumienie przeszkody publicznej u Grabowskiego nie zależało od tego, czy mowa była o konwalidacji nieważnie zawartego małżeństwa, czy też o dyspensowaniu od przeszkód przed jego zawarciem $^{41}$.

Zbliżone do Grabowskiego poglądy prezentował Gieran. Twierdził, że przeszkody publiczne ze swej natury nie mogą być uznane za przeszkody tajne, nawet wtedy, gdy nie ma możliwości udowodnienia ich istnienia na forum zewnętrznym, czyli w sądzie kościelnym. Z opinią tą polemizował Petrovits. Wskazywał, że ustawodawca w can. 1037 CIC/17 celowo użył słowa censetur (uważa się) zamiast słowa est (jest), aby zawęzić zakres pojęcia przeszkody publicznej tylko i wyłącznie

39 TAMŻE, s. 673.

40 S. Biskupski, Prawo małżeńskie Kościoła rzymskokatolickiego..., s. 106-107.

41 I. Grabowski, Prawo kanoniczne, Warszawa 1948, s. 368-369. 
do tych przeszkód, które mogą być udowodnione na forum zewnętrznym. Posiadanie dowodu semi-plena, jak zauważał Petrovits, nie było wystarczające do tego, aby przeszkodę uznać za publiczną. Potrzebny był do tego dowód pełny (probationem plenam). Według autora, zgodnie z normą zapisaną w can. $1037 \mathrm{CIC} / 17$, za przeszkodę publiczną nie można uznać przeszkody pokrewieństwa zachodzącej między dwoma stronami, której istnienia nie można udowodnić na forum zewnętrznym. Wiedza jednej ze stron zawierających małżeństwo o jej istnieniu nie zmienia tej kwalifikacji. Z drugiej strony, jeśli przeszkoda występku może zostać udowodniona, wtedy musi być traktowana jako przeszkoda publiczna. W takiej sytuacji, zdaniem Petrovitsa, ucieczka osoby winnej przestępstwa w odległe miejsce, gdzie występek nie jest znany, nie skutkuje tym, że przeszkoda publiczna staje się tajna, znana jest bowiem cały czas w miejscu wcześniejszego zamieszkania ${ }^{42}$.

Lydon $^{43}$ jako przykład publicznych przeszkód, które mogą być udowodnione na forum zewnętrznym, podawał przeszkodę pokrewieństwa i przeszkodę różnicy religii. Obydwie z nich były zaliczane przez prawników do przeszkód publicznych ze swej natury. Jego zdaniem do udowodnienia istnienia przeszkody w chwili zawierania małżeństwa i tym samym nieważności małżeństwa, wystarczały dowody z dokumentów lub dwóch dobrych świadków. Niestety, autor nie wyjaśnił, co miał na myśli, pisząc o „dobrych” świadkach. Prawdopodobnie chodziło o takich świadków i takie zeznania, które będą mogły stanowić wystarczający dowód do orzeczenia nieważności małżeństwa w procesie małżeńskim. Autor podkreślał, że terminu „publiczny” z can. 1037 CIC/17 nie należy utożsamiać z terminem "publiczny” z can. 2197 CIC/17, gdzie była mowa o przestępstwach publicznych, w których znaczenie miało to, czy przestępstwo jest lub z pewnością

\footnotetext{
42 J.J. Ch. Petrovits, New Church Law on Matrimony..., s. 73-74, 98.

43 Pierwsze wydanie komentarza Ayrinhaca wskazuje, że poglądy te prezentował Lydon, który poprawił opracowanie Ayrinhaca: H.A. AyrinhaC, Marriage Legislation in the New Code of Canon Law, New York - Boston - Cincinnati - Chicago - San Francisco 1918, s. 75-76; H.A. Ayrinhac, Marriage Legislation in the New Code of Canon Law, (revised and enlarged P.J. Lydon), New York - Boston - Cincinnati Chicago - San Francisco 1952, s. 55, 387.
} 
będzie rozgłoszone. Jego zdaniem większość przeszkód małżeńskich ma charakter publiczny. W uznaniu przeszkód za publiczne nie przeszkadzało, że świadkowie dostarczający dowodów o istnieniu faktu, z którego wynikała przeszkoda, nie mieli w rzeczywistości wiedzy, że jest on przyczyną istnienia przeszkody małżeńskiej ${ }^{44}$.

Pisząc o przypadkach tajnych istnienia przeszkody (casus sit occultus), zauważył, że pojęcie to może obejmować swym zakresem również niektóre przeszkody publiczne. Dla zobrazowania tej tezy przytoczył sytuację, w której, mimo że o istnieniu między mężczyzną i kobietą pokrewieństwa II stopnia w linii bocznej wiedzą zaledwie dwie lub trzy roztropne osoby, co kwalifikuje przeszkodę jako publiczną w rozumieniu can. 1037 CIC/17, to jednak w rzeczywistości przypadek istnienia przeszkody jest tajny w rozumieniu can. 1045 $\$ 3 \mathrm{CIC} / 17$ (it is an occult in fact) ${ }^{45}$. Lydon, kwalifikując przeszkodę z przywołanego przykładu jako publiczną, nie czynił żadnego zastrzeżenia, że owe osoby, które mają wiedzę o istnieniu pokrewieństwa, złożą zeznania o tym fakcie. Można sobie przecież wyobrazić sytuację, że świadkowie mający wiedzę o przeszkodzie nie będą współpracować $\mathrm{z}$ sądem kościelnym i tym samym jej istnienie nie zostanie udowodnione na forum zewnętrznym.

Ayrinhac w pierwszym wydaniu komentarza poprawionego przez Lydona zwracał uwagę, że określenie desygnatów pojęć przeszkód tajnych i przeszkód publicznych przed 1917 rokiem, ale i po promulgacji kodeksu również, zależne było od tego, czy mówi się o nich w kontekście uważnienia małżeństwa, czy też udzielania dyspens przez Penitencjarię Apostolską. W pierwszym przypadku za przeszkodę publiczną uważano tę, którą można udowodnić w sądzie, do czego wystarcza dwóch lub trzech świadków. W drugiej sytuacji za przeszkodę tajną uważano tylko tę, która była tajna ze swej natury i jednocześnie tajna faktycznie (an impediment is considered occult if it is so both by its nature and in fact). Ayrinhac doprecyzował, że

44 H.A. Ayrinhac, Marriage Legislation in the New Code of Canon Law, (revised and enlarged P.J. LydoN)..., [1952], s. 55, 387.

45 TAMŻE, s. 77. 
przeszkoda faktycznie tajna jest wtedy (It is altogether occult in fact if it is known only...), gdy znana jest tylko spowiednikowi i stronom, tajna simliciter zaś, gdy jest znana tylko kilku osobom (pięciu lub sześciu w małym mieście) i nie ma niebezpieczeństwa jej nagłośnienia. Choć Ayrinhac w swoim komentarzu pisał, że podział na przeszkody tajne i publiczne i ich rozumienie są wspólne dla wszystkich norm CIC/17, to w rzeczywistości wiązał ich znaczenie z tym, czy małżeństwo ma być zawarte (i chodzi o dyspensowanie), czy też już zostało zawarte (i chodzi o konwalidowanie) $^{46}$.

Jednym z niewielu autorów, którzy wprost twierdzili, że can. 1037 CIC/17 zawiera jasną definicję przeszkody publicznej i tajnej, był Augustine. Trafnie zauważał, że jedyną różnicę między tymi pojęciami stanowi możliwość udowodnienia ich istnienia zgodnie z zasadami prawa procesowego. O tajnych pisał, że są nimi te przeszkody, co do których należy przypuszczać, że są i pozostaną nieznane. Wyjątkowo o ich istnieniu może wiedzieć jedna lub dwie osoby godne zaufania ${ }^{47}$. Mogą stać się publicznymi, gdy strony będą zainteresowane konwalidacją małżeństwa bądź stwierdzeniem jego nieważności. Oprócz tego publicznymi mogą stać się również wtedy, gdy dwóch wiarygodnych świadków (oprócz zainteresowanej strony lub stron) będzie posiadać odpowiednie środki dowodowe lub gdy będzie istniał autentyczny dokument, który może stanowić pełen dowód ${ }^{48}$. Augustine w swoich komentarzach dotyczących can. 1037 CIC/17 starał się pogodzić prawo przedkodeksowe z prawem obowiązującym po 1917 roku $^{49}$.

Bączkowicz, powołując się na Gasparriego oraz Linneborna, uważał, że przeszkodę można uznać za publiczną wtedy, gdy fakt, z którego

\footnotetext{
46 H.A. Ayrinhac, Marriage Legislation in the New Code of Canon Law, New York - Cincinnati - Chicago..., [1918], s. 77.

47 Świadczy to o tym, że koncentrował się na kryterium rozgłoszenia. Reszta wywodu sugeruje jednak, że za kryterium podziału przeszkód przyjmował „możliwość ich udowodnienia”.

48 Ch.P. Augustine, A Commentary on the New Canon Law. Vol. 5: Marriage Law (can. 1012-1143). Matrimonial Trials (can. 1960-1992), St. Louis - London 1919, s. 84. 49 Odwoływał się do: Sacra Congregatio Concili, Resolutio, 9.07.1881, 10.09.1881, ASS 14 (1881), s. 465.
} 
powstaje przeszkoda jest publiczny, czyli że da się go udowodnić nie tylko hipotetycznie, lecz także praktycznie. Mówiąc o dowodzie praktycznym, miał na myśli przeprowadzenie dowodu zgodnie z zasadami prawa. Ponieważ twierdził, że w przypadku przeszkód publicznych potencjalni świadkowie nie musieli być świadomi tego, że fakty, co do których zeznają są przyczyną istnienia przeszkody, tym samym dystansował się od podziału przeszkód na publiczne i tajne formalnie bądź materialnie (formaliter vel materialiter) ${ }^{50}$.

Poglądy zbliżone do Bączkowicza prezentował Sztafrowski. Również i on odwoływał się do podziału przeszkód małżeńskich, jaki istniał przed wejściem w życie norm kodeksu Pio-Benedyktyńskiego. Odcinał się od jednakowej interpretacji pojęcia „publiczny” z can. 1037 CIC/17 i can. 2197 CIC/17. Jednak uzasadniając istniejące różnice między tymi normami, popełnił błąd logiczny. Według niego w prawie karnym przestępstwo uważa się za publiczne wtedy, gdy zostało ono rozgłoszone, czyli gdy informacja o nim dotarła do pewnej grupy osób. Natomiast przeszkoda małżeńska jest publiczna wtedy, gdy istnieje możliwość jej udowodnienia w zakresie zewnętrznym, czyli rozgłoszenia, która na razie nie musi istnieć ${ }^{51}$. Jako przykład przeszkody publicznej opisał przeszkodę z natury swojej publiczną ${ }^{52}$. Pogląd Sztafrowskiego miał słabe strony. Wernz zwracał bowiem uwagę, że rozgłoszenie i wiedza o niej (notitia i divulgatio) nie zawsze musi iść $\mathrm{w}$ parze $\mathrm{z}$ możliwością udowodnienia istnienia przeszkody na forum sądowym. Uważał, że przeszkoda $z$ natury swojej publiczna może być przeszkodą faktycznie tajną (quo in casu dicebatur facto occultum), kiedy z powodu okoliczności nie jest znana innym lub jest znana tylko niewielu i wtajemniczonym osobom, tak że $\mathrm{z}$ powodu przymiotu miejsca nie ma ryzyka rozpowszechnienia się ${ }^{53}$.

\footnotetext{
50 F. Bączkowicz, J. Baron, W. Stawinoga, Prawo kanoniczne. Podręcznik dla duchowieństwa, t. 2..., s. 181.

51 E. Sztafrowski, Prawo kanoniczne w okresie odnowy soborowej, t. 2..., s. 231.

52 TAMŻE, s. 225.

53 F.Xav. Wernz, P. Vidal, Ius Canonicum, t. V. Ius Matrimoniale..., s. 178-179.
} 
Skoro mowa o Wernzu, to trzeba zauważyć, że autor ów komentując can. 1037 CIC/17, dokonał podziału przeszkód małżeńskich ze względu na sposób dowodzenia ich istnienia w sądzie. W związku z tym wyróżnił przeszkody faktycznie publiczne (impedimentum facto publicum) i z natury swojej publiczne (natura publicum). Przeszkodą faktycznie publiczną (facto publicum) jest taka, która jest notoryczna (notorium), czy to na mocy powszechnej znajomości prawa (notorietate iuris), czy to na mocy powszechnej znajomości faktu (notorietate facti), lub przynajmniej znajduje się w takich okolicznościach, że przeszkoda może zostać prawnie dowiedziona.

Warto zauważyć w tym miejscu, że opis ten (quod est notorium sive notorietate iuris sive notorietate facti) analogiczny jest do definicji kodeksowej pojęcia przestępstw notorycznych, zapisanej w can. 2197 CIC/17. Na zasadzie analogii należałoby zatem przyjąć, że przeszkodą faktycznie publiczną na mocy powszechnej znajomości prawa jest ta, której przyczyna lub sama przeszkoda zostały stwierdzone wyrokiem sądowym, który przeszedł w stan rzeczy osądzonej, albo gdy winny ${ }^{54}$ z zachowaniem normy zapisanej w can. 1750 CIC/17 przyznał się przed sądem do ich popełnienia. Natomiast przeszkoda jest faktycznie publiczna na mocy powszechnej znajomości faktu, gdy czyn (związany z przyczyną przeszkody) jest tak publiczny, iż żadnym wykrętem nie można go ukryć oraz w żaden legalny sposób nie można go ${ }^{55}$ wykluczyć.

Zdaniem Wernza, według prawa obowiązującego po 1917 roku przeszkodą publiczną była także ta przeszkoda, która na mocy przedkodeksowego prawa regulującego kwestie dyspensowania od przeszkód, określana była mianem przeszkody quasi occultum lub simpliciter occultum, czyli również taka, która mogła być znana 5, 10 lub 12 osobom, stosownie do różnych okoliczności, a jednak nadal nie było ryzyka jej rozpowszechnienia. Dla uznania przeszkody, według prawa obowiązującego po promulgacji CIC/17, za faktycznie tajną (iure

\footnotetext{
54 Lub ten, kto jest sprawcą przyczyny przeszkody.

55 Tak samo nie można wykluczyć poczytalności, jeśli była konieczna do zaistnienia przyczyny, na której opiera się przeszkoda.
} 
novo facto occultum dumtaxat haberi illud impedimentum), powinna być ona znana jedynie stronom, spowiednikowi oraz jednej osobie. Czyli według prawa przedkodeksowego powinna być ona przeszkodą omnino occultum.

Jeśli chodzi o przeszkody małżeńskie publiczne z natury (natura publicum), autor definiował je tak samo jak kanoniści przed promulgacją kodeksu Pio-Benedyktyńskiego. Według niego rodziły się one $\mathrm{z}$ faktu samego $\mathrm{z}$ siebie publicznego (ex facto de se publico). Takimi faktami były te, które wydarzyły się w sądzie kościelnym lub w zgromadzeniu wiernych (np. z nich powstawała przeszkoda święceń kapłańskich, uroczystych ślubów lub zwykłych ślubów w jakimś zakonie). Były nimi również te, który zostały odnotowane w rejestrach publicznych (rodziła się z nich np. przeszkoda wieku, pokrewieństwa prawowitego, powinowactwa, pokrewieństwa duchowego i prawnego, różnicy wiary i religii). Faktami z natury publicznymi były także te, których można było dowieść na podstawie zeznań świadka kwalifikowanego w sprawach, którymi świadek ów zajmował się z urzędu (np. przy przeszkodzie węzła pochodzącej z małżeństwa zawartego wobec proboszcza lub przynajmniej dwóch świadków). Wernz zauważył, że przeszkoda $\mathrm{z}$ natury publiczna (impedimentum natura publicum), lecz faktycznie tajna (sed facto occultum), powinna być uważana za przeszkodę publiczną (habendum est publicum) kiedy jej dowodzenie może się dokonać w sądzie zewnętrznym ${ }^{56}$.

Podobnie do Wernza przeszkody publiczne i tajne w swoim komentarzu do CIC/17 interpretował Jone. Pisząc o przeszkodzie publicznej, i to - jak sam zauważył - faktycznie publicznej (facto publicum), stwierdził, że jest to przeszkoda znana dwóm lub trzem osobom. By wiedza owych osób była wystarczająca do uznania przeszkody za publiczną, musiały one spełnić warunki zapisane w can. $1791 \S 2$ CIC/17. Zgodnie z normą w nim zapisaną dwóch lub trzech świadków, by ich zeznania można było uznać za wystarczający dowód, powinno odznaczać się wiarygodnością i przed sądem zupełnie zgodnie zeznać o tej samej rzeczy lub fakcie pod przysięgą, na podstawie własnej

56 F. Xav. Wernz, P. Vidal, Ius Canonicum, t. V. Ius Matrimoniale..., s. 179-180. 
wiedzy. Śmierć świadków przy braku innych dowodów wystarczających skutkowała tym, że przeszkoda publiczna stawała się przeszkodą tajną. Według Jone przeszkodami publicznymi były również przeszkody z natury swojej publiczne, gdy ich istnienia można było dowieść dokumentem publicznym (np. adnotacją w księgach, gdzie zapisuje się fakt chrztu, małżeństwa, zgonu, złożenia ślubów zakonnych, przyjęcia święceń) lub wyrokiem, który przeszedł w stan rzeczy osądzonej. W tym przypadku bez znaczenia było to, czy osoby, którym przeszkoda była znana, jeszcze żyją. Gdy dokumenty publiczne zaginęły i nie można było przez świadków dowieść istnienia przeszkody, przeszkodę mimo wszystko nazywano tajną.

Jone za częścią kanonistów uważał, że nie we wszystkich przepisach kodeksu termin impedimentum publicum znaczy dokładnie to samo. CIC/17 większość uczonych aplikuje do wyjaśnienia normy zapisanej w can. 1133 CIC/17 (i następnych), gdzie jest mowa o CIC/17, oznacza on już co innego. W tych przypadkach wydaje się on opisywać przeszkody, które są znane większej liczbie osób lub mające miejsce w takich okolicznościach, że można zasadnie wnioskować, iż łatwo mogą zostać rozgłoszone (divulgatum). Wtedy termin publicum styka się z pojęciem deliktu publicznego (delictum publicum) uregulowanym w can. $2197 \mathrm{CIC} / 17^{57}$.

Nieco odmiennie od wcześniej wymienionych autorów pojęcie przeszkody publicznej interpretował Cappello. Niejako automatycznie zakwalifikował przeszkody z natury swojej publiczne (natura sua publicum) do przeszkód publicznych. Dopiero w przypadku przeszkód z natury swojej tajnych zaliczenie ich do przeszkód publicznych uwarunkował możliwością przeprowadzenia dowodu na forum zewnętrznym. Dla Cappella możliwość udowodnienia istnienia przeszkody wiązała się z tym, że przyczyna przeszkody ze swej natury tajna zaistniała w takich okolicznościach, że wiedza o niej doszła do wiadomości ludzi lub została ona już tak poznana, że dotarcie do wiadomości innych osób jest prawdopodobne (si factum est quidem

57 H. Jone, Commentarium in Codicem Iuris Canonici, t. 2, Padeborn 1954, s. 241-242, 375 (przywołane fragmenty tłumaczył Robert Sochań). 
natura sua occultum, sed iam divulgatum aut saltem ita cognoscitur, ut divulgatio probabilis sit et inde possibilis evdat probatio in foro externo). Zauważał, że wszelka przeszkoda notoryczna (notorium) jest przeszkodą publiczną, ale nie na odwrót. Nie każda przeszkoda publiczna (impedimentum publicum) jest przeszkodą notoryczną w rozumieniu can. 2197 CIC/17. Podkreślał, że istotnym elementem, który trzeba mieć na uwadze przy kwalifikacji przeszkód jako publiczne, nie jest bynajmniej ich rozgłoszenie (upowszechnienie), ale możliwość ich udowodnienia na forum zewnętrznym. W związku $\mathrm{z}$ tym publiczną jest również ta przeszkoda, która została poznana dzięki dwom wiarygodnym świadkom, a nawet tylko dzięki jednemu, np. dzięki świadkowi kwalifikowanemu.

Cappello prezentował pogląd, że definicja ustawowa przeszkody publicznej z can. 1037 CIC/17 była wspólna dla wszystkich przepisów prawa obowiązującego po 1917 roku, w których występowało pojęcie impedimetum publicum. Jedyny wyjątek po promulgacji kodeksu Pio-Benedyktyńskiego stanowiła sytuacja, w której występowano o dyspensę od przeszkód małżeńskich do Penitencjarii Apostolskiej. Zdaniem kanonisty w myśl obowiązującego po 1917 roku prawa przeszkodami tajnymi były wyłącznie te przeszkody, które zgodnie $\mathrm{z}$ prawem przedkodeksowym określano terminem impedimentum omino occultum. Uczony do ostatnich zaliczał przeszkody znane tylko spowiednikowi i nupturientom, wskutek czego nie mogły być udowodnione nawet przez dwóch świadków, oraz te, których nie można było udowodnić w inny sposób. Do uznania przeszkody za publiczną nie było konieczności posiadania wiedzy, że z faktu publicznego (factum sit publicum), który może być udowodniony na forum zewnętrznym, w rzeczywistości powstaje przeszkoda. Jednakże, gdyby fakt, z którego powstała przeszkoda, był znany tylko po części, nie zaś wedle wszystkich elementów konstytutywnych przeszkody, wtedy przeszkoda uznawana była za tajną (impedimentum occultum). Jako przykład Cappello podał przeszkodę małżonkobójstwa, gdzie fakt zabójstwa został poznany, ale przestępstwo to nie zostało 
przypisane. Wtedy przestępstwo w rzeczywistości było uznawane za tajne i przeszkoda małżonkobójstwa była tajna ${ }^{58}$.

\section{Zakończenie}

Po promulgacji Kodeksu prawa kanonicznego w 1917 roku wydawać by się mogło, że kanoniści nie będą mieli już dłużej jakichkolwiek wątpliwości przy określaniu zakresu pojęć przeszkody publicznej i przeszkody tajnej. Wszelkie trudności powinny zniknąć wraz z ustawowym zdefiniowaniem przez najwyższego ustawodawcę, w can. 1037 CIC/17, terminów impedimentum publicum i impedimentum occultum. Autorzy piszący po 1917 roku, opierając się na tej definicji, w zdecydowanej większości byli zgodni, że kryterium podziału owych przeszkód małżeńskich stanowiła możliwość przeprowadzenia zgodnie z normami prawa procesowego dowodu co do istnienia przeszkody w chwili zawierania małżeństwa. Na tym jednak owa zgodność się kończyła.

Swój przyczynek w pojawieniu się zamieszania z pewnością miała Penitencjaria Apostolska, która po ogłoszeniu kodeksu Pio-Benedyktyńskiego, przy udzielaniu na forum wewnętrznym dyspens od przeszkód tajnych, interpretowała je nadal według własnej stałej praktyki przedkodeksowej, odmiennej od definicji przeszkody tajnej, zapisanej w can. 1037 CIC/17. Ponadto Papieska Komisja ds. Autentycznej Interpretacji Kanonów Kodeksu, autentycznie interpretując przedmiotową normę dnia 25 czerwca 1932 roku, odwołała się do niezdefiniowanego w kodeksie pojęcia „faktu publicznego” (sufficiat ut publicum sit factum ex quo oritur impedimentum), co z pewnością nie przyczyniło się do wyeliminowania wciąż pojawiających się trudności w zrozumieniu normy zapisanej w can. 1037 CIC/17. Nie bez znaczenia przy próbie ich rozwiązania było również to, że w dokumentach papieskich, jak np. w konstytucji apostolskiej Servatoris Iesu Christi z 1925 roku,

58 F.M. Cappello, Tractatus canonico-moralis de sacramentis, vol. V. De matrimonio, Roma 1961, s. 190-191 (przywołane fragmenty tłumaczył Piotr Cyciura). 
można było się spotkać z nieznanym w CIC/17 podziałem przeszkód na impedimenta prorsus occulta i impedimenta occulta.

Brak konsekwencji ze Strony Stolicy Apostolskiej w określeniu zakresu przeszkód oraz przywiązanie kanonistów do schematów wypracowanych w doktrynie przez setki lat spowodowały, że prawo obowiązujące w latach 1917-1983, a także sam podział przeszkód małżeńskich, uczeni usiłowali tłumaczyć prawem przedkodeksowym, do którego chwilami usiłowali dostosować „nowe prawo”. Doskonały przykład przywiązania do „starego prawa” stanowiło chociażby stawianie przez niektórych autorów znaku równości między przeszkodami publicznymi ze swojej natury i przeszkodami publicznymi. Często komentatorów przepisów kodeksu Pio-Benedyktyńskiego cechował brak konsekwencji w opisywaniu przeszkód publicznych i tajnych. Określenie zakresów pojęć w doktrynie i dyscyplinie uzależnione było od tego, czy do pojęć impedimentum publicum i impedimentum occultum odwoływano się ze względu na wskazanie podmiotów kompetentnych do udzielenia dyspensy od przeszkody małżeńskiej, czy też ze względu na wyznaczenie sposobu konwalidowania nieważnie zawartego małżeństwa w obliczu Kościoła.

W związku z powyższym nie ma się co dziwić, że cytowany Woywod zalecał zachowanie ostrożności przy lekturze opracowań i komentarzy can. 1037 CIC/17.

\section{References}

\section{Źródła}

Codex Canonum Ecclesiarum Orientalium auctoritate Ioannis Pauli PP. II promulgatus, 18.10.1990, Typis Polyglottis Vaticanis 1990.

Codex Iuris Canonici auctoritate Ioannis Pauli PP. II promulgatus, 25.01.1983, AAS 75 (1983), pars II, s. 1-317.

Codex Iuris Canonici Pii X Pontificis Maximi iussu digestus. Benedicti Papae XV auctoritate promulgatus, 15.09.1917, Romae 1917, AAS 9 (1917) II.

Kodeks prawa kanonicznego, przekład polski zatwierdzony przez Konferencje Episkopatu (25.01.1983), Pallottinum, Poznań 1984.

Kodeks kanonów Kościołów wschodnich promulgowany przez papieża Jana Pawła II (18.10.1990), Wydawnictwo Archidiecezji Lubelskiej „Gaudium”, Lublin 2002. 
PiUs XI, Constitutio Apostolica Universale Iubilaeum Anno Domini Millesimo Nongentesimo Vicesimo Quinto in Urbe Celebratum ad Totum Catholicum Orbem Extenditur Servatoris Iesu Christi, 25.12.1925, AAS 17 (1925), s. 611-618. PIUs XI, Konstytucja apostolska Sacerdotis Iesu Christi, na stronie https://opoka. org.pl/biblioteka/W/WP/pius_xi/konstytucje/jubileusz_25121925.html (dostęp 2.01.2021 r.).

PIUs XII, Motu proprio de disciplina sacramenti matrimonii pro Ecclesia Orientali Crebrae allatae sunt, 22.02.1949, AAS 41 (1949), s. 89-119.

Pontificia Commissio ad Codicis Canones Authentice Interpretandos, Responsa ad proposita dubia, 25.06.1932, AAS 24 (1932), s. 284-285.

Sacra Congregatio Concili, Resolutio 9.07.1881, 10.09.1881, ASS 14 (1881), s. $464-465$.

Sacra Congregatio Sancti Concilit, Mohiloven. seu Tiraspolen., 9.07.1881, 10.09.1881, w: P. Gasparri, Codicis Iuris Canonici Fontes, vol. 6, Typis Polyglottis Vaticanis, Roma 1962, n. 4253, s. 639-641.

Sacra Romana Rota, Nullitatis matrimonii (Andrassy-Széchényi), c. Michael Lega, 2.06.1911, AAS 4 (1915), s. 108-118.

Sacra Romana Rota, Nullitatis matrimonii (Pic-Garreaud), c. Guilelmus Sebastianelii, 26.04.1916, AAS 9 (1917-I), s. 144-150.

Sacra Romana Rota, Nullitatis matrimonii (Pic-Garreaud), c. Ioannes Prior, 21.05.1915, AAS 8 (1916), s. 45-51.

\section{Literatura}

Augustine Ch.P., A Commentary on the New Canon Law. Vol. 5: Marriage Law (can. 1012-1143). Matrimonial Trials (can. 1960-1992), B. Herder Book Co., St. Louis - London 1919.

Ayrinhac H.A., Marriage Legislation in the New Code of Canon Law, Benziger Brothers, New York - Boston - Cincinnati - Chicago - San Francisco 1918.

Ayrinhac H.A., Marriage Legislation in the New Code of Canon Law, (revised and enlarged P.J. Lydon), Benziger Brothers, New York - Boston - Cincinnati Chicago - San Francisco 1952.

Bączkowicz F., Baron J., Stawinoga W., Prawo kanoniczne. Podręcznik dla duchowieństwa, t. 2, Wydawnictwo Diecezjalne św. Krzyża w Opolu, Opole 1958.

Bączkowicz F., Baron J., Stawinoga W., Prawo kanoniczne. Podręcznik dla duchowieństwa, t. 3, Wydawnictwo Diecezjalne św. Krzyża w Opolu, Opole 1958.

Biskupski S., Prawo małżeńskie Kościoła rzymskokatolickiego, t. 1, PAX, Warszawa 1956.

Canon Law Digest. Officially Published Documents Affecting the Code of Canon Law 1917-1933, vol. 1, T. Lincoln Bouscaren (red.), The Bruce Publishing Company Milwaukee, Milwaukee 1934. 
Canon Law Digest. Officially Published Documents Affecting the Code of Canon Law 1933-1942, vol. 2, T. Lincoln Bouscaren (red.), The Bruce Publishing Company, Milwaukee 1934.

CAPPELlo F. M., Tractatus canonico-moralis de sacramentis, vol. V. De matrimonio, Marietti, Roma 1961.

GasParri P., Tractatus canonicus de matrimonio, v. 1, Libraria Delhomme et Briguet, Parisiis 1904.

Grabowski I., Prawo kanoniczne, Gebethner i Wolff, Warszawa 1948.

Jone H., Commentarium in Codicem Iuris Canonici, t. 2. Officina Libraria F. Schöningh, Padeborn 1954.

Meenan A.B., The New Canon Law in its Practical Aspects, American Ecclesiastical Review, The Dolphin Press Philadelphia 1918.

Petrovits J.J.Ch., New Church Law on Matrimony, Philadelphia 1919.

Sztafrowski E., Prawo kanoniczne w okresie odnowy soborowej. Podręcznik dla duchowieństwa, t. 2, Akademia Teologii Katolickiej, Warszawa 1979.

Wernz F. Xav., Vidal P., Ius Canonicum, t. V. Ius Matrimoniale, Apud Aedes Universistatis Gregorianae, Roma 1946.

Woy wod S., A Practical Commentary on The New Canon Law, vol. 1, Joseph F. Wagner (Inc.) - B. Herder, New York - London 1948.

\section{Nota o autorze}

Ks. Tomasz Jakubiak - doktor habilitowany nauk prawnych w dyscyplinie prawa kanonicznego, profesor Akademii Katolickiej w Warszawie (dawny Papieski Wydział Teologiczny w Warszawie). 